\title{
Logistics Concepts to Optimise Business Processes
}

\author{
OLHA PROKOPENKO ${ }^{*}$, YAROSLAV KICHUK ${ }^{2}$, OLENA PTASHCHENKO ${ }^{3}$, IGOR YURKO ${ }^{4}$, \\ MAIIA CHERKASHYNA ${ }^{5}$ \\ $1^{1 *}$ Department of Economics, COLLEGIUM MAZOVIA INNOVATIVE UNIVERSITY, POLAND. \\ E-mail: prokopenko.olha.w@gmail.com \\ ${ }^{2}$ Department of Law and Social Work, IZMAIL STATE UNIVERSITY OF HUMANITIES, UKRAINE. \\ ${ }^{3}$ Department of International Business and Economic Analysis, S.KUZNETS KHARKIV NATIONAL UNIVERSITY OF \\ ECONOMICS, UKRAINE. \\ ${ }^{4}$ Department of Entrepreneurship, Trade and Exchange Activities, POLTAVA UNIVERSITY OF ECONOMICS AND \\ TRADE, UKRAINE. \\ ${ }^{5}$ Department of Management and Military Economy, NATIONAL ACADEMY OF NATIONAL GUARD OF UKRAINE, \\ UKRAINE.
}

\begin{abstract}
The need to rethink traditional approaches to optimising business processes is forcing enterprises to find new ways to manage them. The article proposes a methodology for optimising processes based on integrated pulling logistics technology. The basic principles, rules and concepts of logistic activity are considered, as well as methods of optimisation and their implementation for enterprises of any form of ownership without changes to the already involved logistic systems are proposed. The features of the application of the optimisation methodology with the use of pulling logistics technologies, both to the business process as a whole and its individual elements, are indicated. Particular attention is paid to the weak and strong sides of the proposed methodology, and also in the experimental part, an approach to adapting this methodology in practice is presented.
\end{abstract}

Keywords: business processes, economic system, logistics concept, optimisation.

JEL Classification: D23, L25, P46 


\section{Introduction.}

The dynamic development of modern economic systems, which include enterprises, is a common phenomenon in the contemporary business world. Any organisation wishing to survive in a rapidly changing market environment is forced to create a complex flexible business system, taking into account the organisational, information and technological aspects of its activities (Dzwigol \& DzwigolBarosz, 2020; Kuzior et al., 2019; Balan et al., 2020; Prokopenko et al., 2020a).

The business process in the economic activity of any company, are interrelated actions that implement one or more of the business goals of the company, consisting of many internal steps or movements, starting with one or more inputs and ending with the creation of products or services necessary for customers and satisfying them in terms of cost, quality and timing (Maleyeff, 2020; Prokopenko et al., 2020b).

Nowadays, companies are almost always viewed from the perspective of the business processes they cover. Business process management means their constant optimisation; therefore, approaches and methods for improving business processes are the most critical management tools (Oliinyk et al., 2018; Mhanna, Ali \& Hejase, 2020). Of course, this also applies to logistics business processes (Shpak et al., 2016).

Integration is the main idea underlying the logistic approach to organising and managing the company's business processes. This is because flows of materials, resources, finance and information that exist independently at technically independent stages and stages of activity can be interconnected through a standard management system, which can have a significant economic effect (Quezada-Téllez \& Pérez, 2018; Oliinyk \& Kozmenko, 2019). The relationship between the company's strategy, its goals and the role of logistics in its economic activity can be clearly illustrated through the diagram in Fig.1.

Figure 1. The scheme of integration of logistic approaches in the general flow of economic activity of the company

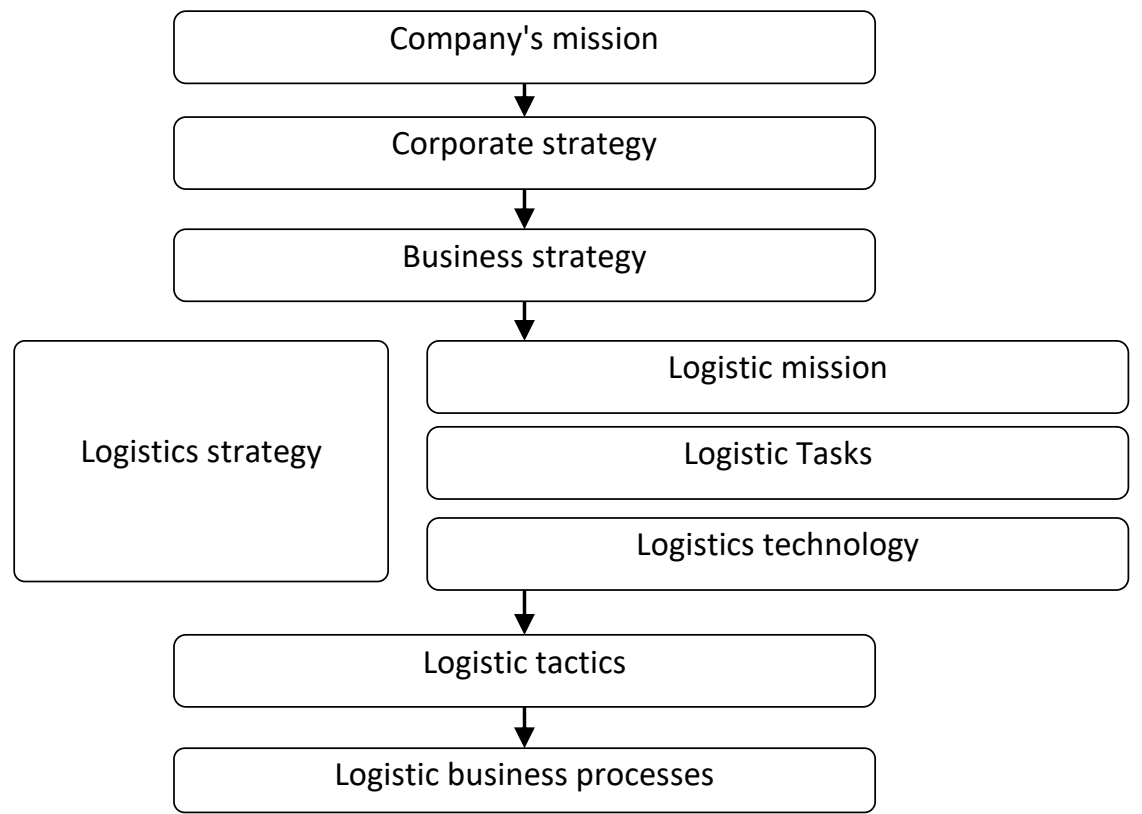

Source: developed by authors based on (Manzini et al., 2011; Spofford et al., 2011; Sezer \& Abası, 2017).

Logistics technologies, from optimising business processes, are primarily focused on managing flows (material, service - basic; financial, information - related) to reduce overall costs and meet the requirements for the quality of products and services and should become an integrated tool for management and business organisation, contributing to the achievement of its strategic, tactical, operational goals. 


\section{Methodology.}

\subsection{Key principles and concepts of logistics systems.}

Before talking about the integration of logistics concepts into business processes, it is worth mentioning the seven basic rules of logistics, schematically presented in Fig.2. Understanding their importance, as fundamental principles, is the key to competent and efficient construction of a logistics system of any type and complexity.

Figure 2. Seven fundamental rules of the logistics system

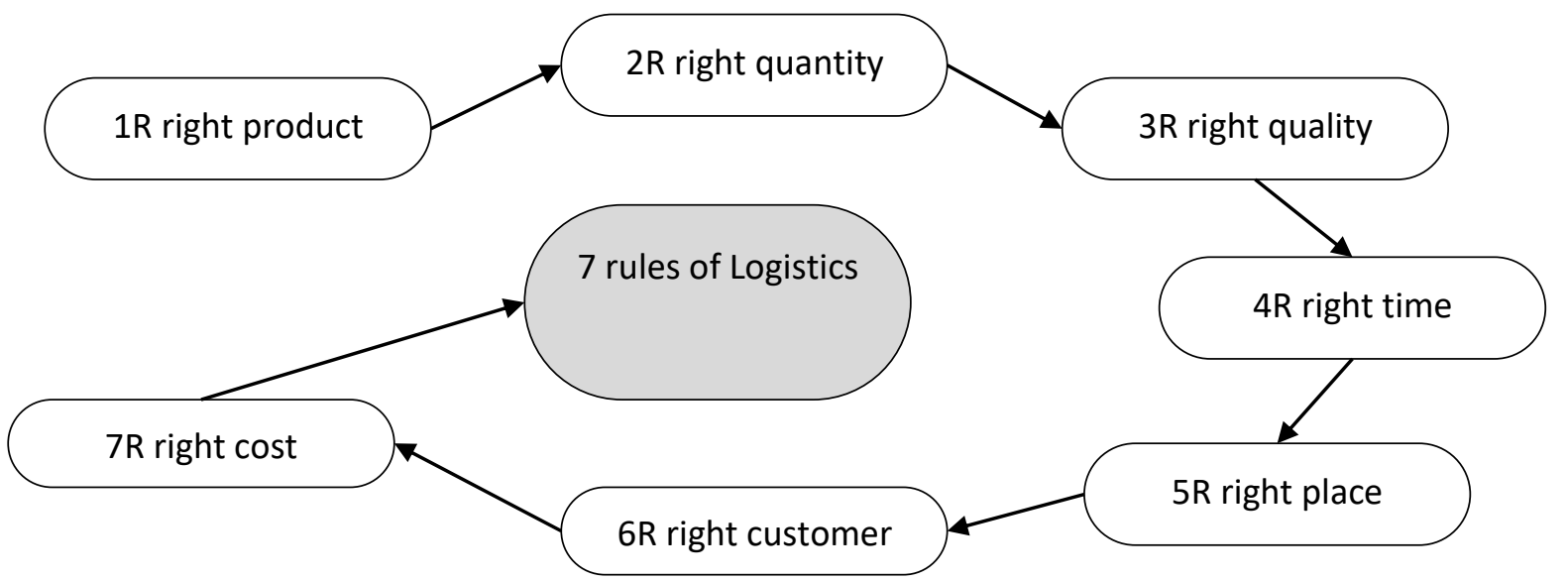

Source: developed by authors based on (Butcher \& Rowley, 1998).

At the same time, optimisation of logistics processes in systems of any kind is aimed at achieving optimal parameters of functioning, both of individual elements and the entire system as a whole (Safran, Babić \& Tomasic, 2008). The criterion for the optimality of the functioning of logistics processes can be represented in the form of the following formula:

$$
L=f\left(\begin{array}{c}
1 R \rightarrow \text { opt }, 2 R \rightarrow \text { opt }, 3 R \rightarrow \max , \\
4 R \rightarrow \text { opt }, 5 R \rightarrow \min , 6 R \rightarrow \text { opt }, 7 R \rightarrow \min
\end{array}\right) \rightarrow \min
$$

In this expression, finding the optimal parameters for each of the components will ultimately lead to the achievement of the most significant economic effect when applied to the logistics process.

The need to apply and implement logistics technologies in business processes is dictated by common sense tied to economic efficiency.

Considering the impact of logistics operations at the micro-level of a particular company, it should be borne in mind that in this context, the mission of logistics is based on providing specific benefits that it can bring if it is used effectively. For example, to promote the growth of the company's competitive advantages, by reducing costs and influencing the process of increasing the value of manufacturing products.

The introduction of logistics concepts can help optimise business processes by:

- reducing stocks at various stages of the movement of material assets,

- reducing downtime and accelerating the promotion of goods,

- reduction and optimisation of transport costs,

- reducing the share of manual labour and optimising the value of cargo operations.

Speaking about the optimisation of business processes using technologies and concepts of logistics, one should, first of all, determine what fundamental principles logistics is based as a scientific, economic system. It should be noted that in current economic conditions, the construction of an effective logistics system cannot be imagined without observing these principles (Al-Dabag, 2005; Azimov, 2018; Sherstennykov, 2019): 
The principle of consistency assumes an approach to the objects of the logistics system as an integrated system; this allows you to optimise the material flow along the entire path of its advancement from the primary source of raw materials to the final consumer. As a result, all links in the logistics chain act as a single mechanism.

The principle of minimising costs. Cost minimisation is one of the main tasks of logistics. This approach consists in analysing and identifying various kinds of values to reduce them.

The principle of global optimisation. The effectiveness of achieving goals in logistics depends on the compliance of local tasks with the strategic objectives of the entire system to achieve an overall result.

The principle of logistics coordination and integration. To achieve specific goals is necessary to integrate all the subjects of management activity into the system, to coordinate the activities of all supply chains in the system.

The principle of optimal development of logistics services. Optimal development of logistics services contributes to the increase in the company's competitiveness and, accordingly, the development of the logistics system as a whole. Logistic service is presented in various forms - from packing, unloading and loading to timely delivery in convenient lots.

The principle of sustainability and adaptability. The external environment is characterised by a high degree of uncertainty in macroeconomic indicators, price volatility, market demand for goods and services, etc. With significant external influences, the company needs to have a stable economic situation and be able to adapt to new conditions promptly.

The principle of total quality control. Ensuring high-quality operation of each element of the logistics network contributes to the efficient functioning of the entire system.

Considering the issue of applying logistics concepts in order to optimise business processes, it should be borne in mind that the very essence of the idea implies a kind of paradigm, or in other words, a business support platform and a toolkit for optimising company resources in managing the primary and accompanying business processes.

The construction of a modern integrated business process management system that implements logistic principles and approaches will help to solve such problems as ensuring stable economic ties, maintaining a competitive environment, and stimulating enterprise development.

From a business perspective, logistics exist to ensure that inventory arrives at the right time, in the right place and with the proper benefit at the lowest total cost. Stocks alone are of little value unless they are placed where and when they are needed to support the transfer of property from hand to hand or create added value. If the company fails to comply with this condition of time and place consistently, it will have nothing to sell. For logistics to bring maximum strategic benefits, all of its functional links must work based on integration.

Success in each such link is meaningful only if it helps to improve the efficiency of the integrated logistics system as a whole. The achievement of the strategic goals of any enterprise depends on the integration of logistics functions.

\subsection{Integration of logistics concepts into business processes.}

Business process management based on a logistic approach assumes that this approach takes into account not only the factor of efficient use of limited resources, but also the efficiency of their movement, and hence the elements of space and time. The use of logistics concepts in the management of business processes will not only optimise the movement and use of resources but also ensure the highest final economic effect from the results of their functioning $(\mathrm{Wu} \&$ Chaipiyaphan, 2019).

In the traditional system of organising the business of an enterprise, logistics functions are usually dispersed between different departments, for example, inventory management issues can be concentrated in the financial department, the supply of raw materials is under the responsibility of 
the technical department, and the marketing of finished products can be assigned to the marketing department. In such cases, business process management seems to be useful, but with this approach, the amount of spending on logistics activities also increases, because each of the divisions has its own goals and methods of reducing costs due to the specifics of its activities (Arshinina \& Kiseleva, 2020). With this approach, a poorly controlled increase in prices for individual business processes is possible, precisely because of the fragmented management of logistics activities, the conflict of interests of individual business units, poor coordination of activities and difficult exchange of relevant information and the general growth of stocks of various types.

A diagram of potential opportunities for integrating logistics technologies into the business processes of an enterprise is shown in Fig. 3.

The integration processes of logistics technologies should be determined by the strategy of the economic development of the enterprise, and the analysis of the business processes that make up its activities, the critical task of this is to ensure the effective functioning of the entire system as a whole and its comprehensive and comprehensive development.

The procedure for optimising business processes using integrated logistics technologies may experience specific difficulties during its implementation. Implementation problems may be associated with low reactivity to the methods of changing traditional organisational structures of the enterprise - this is due to the built and well-tested work scheme, built on the functional responsibilities and powers of existing organisational units. Each division, having its own goals, tasks and terms of reference, although it ensures the implementation of the overall strategy of the enterprise, is nevertheless interested in maintaining the existing status quo, since the worked out scheme of work ensures the fulfilment of the set targets, and any change carries potential risks of the violation.

Optimisation based on logistics concepts will require from the management of structural divisions broader powers, not limited to the formal framework of organisational structures, the ability to promote cross-functional coordination, thus increasing the effectiveness of the enterprise as a whole.

Figure 3. Areas of integration of logistics concepts into business processes of an enterprise

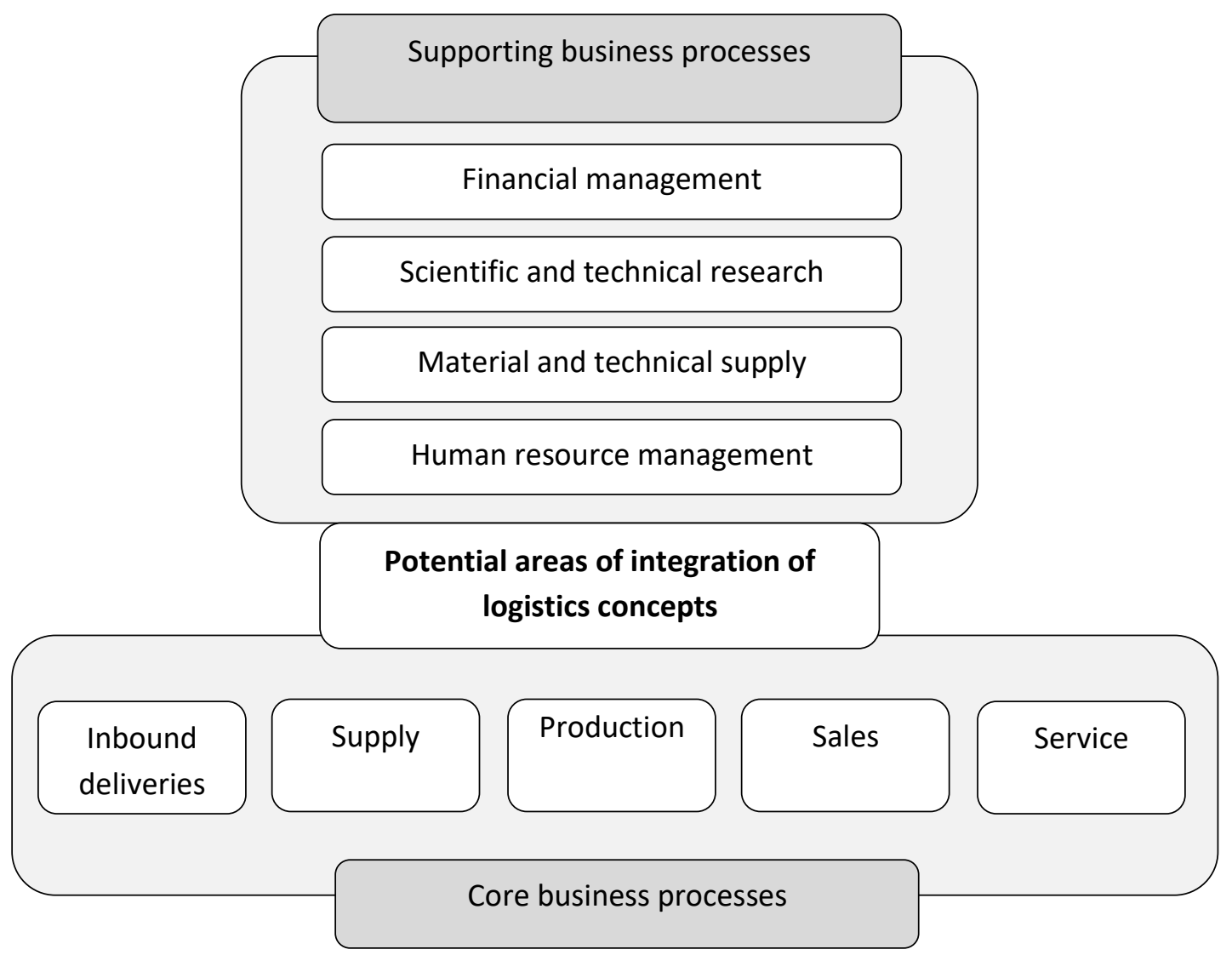


It should also be taken into account that when implementing logistics concepts, one should not expect minimisation of costs in each specific business process. Enterprises should think, first of all, strive to optimise their total costs, even if this increases the costs of a separate business process to some extent.

At the same time, the undoubted advantage of integrating logistics concepts into the business processes of the enterprise will be the presence of the so-called synergistic effect of implementation, in which the performance of two or more divisions integrated into a standard chain gives an impact in economic terms more than each of them will achieve separately, this occurs due to the mutual reinforcement of ties based on integration, reducing the unit total distribution costs, thus contributing to an increase in the efficiency of the functioning of enterprises and thereby allows increasing the competitiveness of enterprises within the framework of joint activities, improving performance indicators in comparison with their independent functioning.

In logistics, there are two fundamental technologies for material flow management: push and pull. The purpose of both technologies is to meet the needs of the following link at the expense of the resource of the previous link. The differences between them lie in the ways of managing flows and the degree of centralisation of supply planning for interlink transmissions.

The key difference between these technologies is the approach to establishing a production rhythm that determines the movement of material flows. The starting point of the pushing concept is the plan, and the pulling one is the demand. Thus, logistics concepts are focused on the different nature of consumer demand.

From integration into business processes to achieve the maximum optimisation effect, this article offers a pulling logistics technology for consideration. The essence of the proposed methodology is to restructure the business processes of an enterprise to organise the flows of material resources in such a way that each subsequent consumer sequentially pulls supplies from the previous link in the chain.

Consequently, a business process organised using pulling logistics technology is characterised by work schedule for only one section, which automatically pulls work schedules for the previous links included in the overall chain of this business process. A schematic diagram of the organisation of work using this technology is shown in Fig. 4.

Figure 4. Integration of pulling logistics technology into the business process

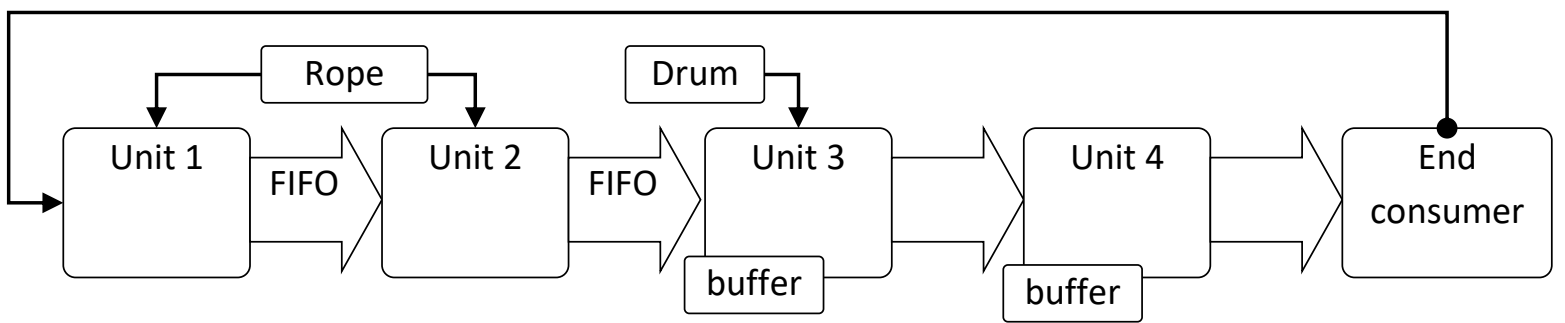

The mechanism for implementing this technology lies in the sequence of the receipt of raw materials, materials, components from the previous to the next link of the business process. The transfer of material resources is carried out on a first-in-first-out (FIFO) basis (Manobar \& Appaiah, 2017; Budiawan, Simanjuntak, Rosely, 2019). The pulling point, that is, the link that sets the overall pace of work, is the final consumer - it can be both the sales department and the external consumerbuyer. The sequence of movement of resources along this chain is strictly defined, while the general rhythm and speed of work are also set. Naturally, with this approach, there will necessarily be sections of the chain that operate at the lowest rate, at these sections will be created, what we will call - a resource limiting business process (RLBP).

For the sections of the chain in front of the areas producing RLBP, a schedule for the release of materials - "rope" will be organised, which will limit the processes of overproduction of non-scarce resources. 
To smooth the flow for the links of the business process, a schedule of work is also created for the release of RBP resources - the so-called "drum", and for the sections following the sections with RLBP, a particular buffer is formed - a stock (but not material), ensuring work taking into account the uneven work of sections with RLBP.

It should be noted that the buffer is temporary, not material since the loss of time at the RLBP link is equal to the loss of time for the entire chain of the business process. Therefore, a buffer is created, a reserve of time that protects the most valuable resource from downtime. It is also worth noting that the process of transferring resources between the sections after passing the RPO no longer occurs according to the first-in-first-out (FIFO) principle, since the performance of links that are not protected by a buffer is obviously higher.

An important feature that potentially provides the priority of integrating pulling logistics technology is its adaptability, which makes it possible to use it, both in the entire business process and in its separate part. In addition, due to such characteristics of pulling logistics technology as flexibility, low cost of production, the business process management system of the enterprise can quickly respond to changes in consumer demands; as a result, it shortens the production cycle, increases the inventory turnover and, in fact, it becomes possible to implement work under the order of specific consumers.

Considering the strengths of the pushing system, one can note its stability, the possibility of organising incoming control, which makes it possible to ensure the satisfaction of stable high demand.

The weaknesses of the pulling principle of flow control are the instability of the system, i.e. a breakdown in one section of the chain leads to a stop of the entire flow. Another factor hindering the effective operation of the system is the high dependence on suppliers, which makes it necessary to work on organising a reliable network of counterparties that can meet the needs of the enterprise in the shortest possible time, with high quality and at a low price.

The general scheme of the enterprise's work with the implemented integration logistics processes, in the domestic and foreign markets, is presented in Fig. 5.

Here, you can immediately identify the strengths and of course, the weaknesses of the organisation of work using business processes with integrated pulling logistics technology.

\section{Strengths of Pulling Technology Business Processes}

1. quick response to changing consumer demands

2. high incoming quality control

3. short production cycle;

4. high inventory turnover;

5. fast changeover of the production line;

6. the ability to work on the order

\section{Weaknesses of pulling technology}

1. the need for the geographical proximity of suppliers;

2. the ability to work exclusively with reliable suppliers;

3. possible costs due to lack of resources to meet consumer needs

The proposed methodology for optimising business processes is based on the logistic concept of limiting the stock of material resources. Still, it makes it possible to regulate it at every stage of the business process, regardless of the operating factors. The pull point, the only point in the system for which there is a work plan, defines the schedule for all other parts of the business process. 


\subsection{Methodology for assessing the effectiveness of the application of logistics concepts to optimise business processes.}

The mechanism for assessing the effectiveness of business processes can be based on a complex system of indicative indicators, while the key of them is to highlight the hand of the profitability of a business process. This factor is based on the process of maximising the price differential between procurement and sale.

$$
V_{\text {prof }}=P_{\text {pur }}-P_{\text {sal }} \rightarrow \max
$$

where $P_{p u r}$ is the purchase price, and $P_{\text {sal }}$ is the selling price.

Figure 5. Scheme of the organisation of work of the enterprise with suppliers and consumers in domestic and foreign markets

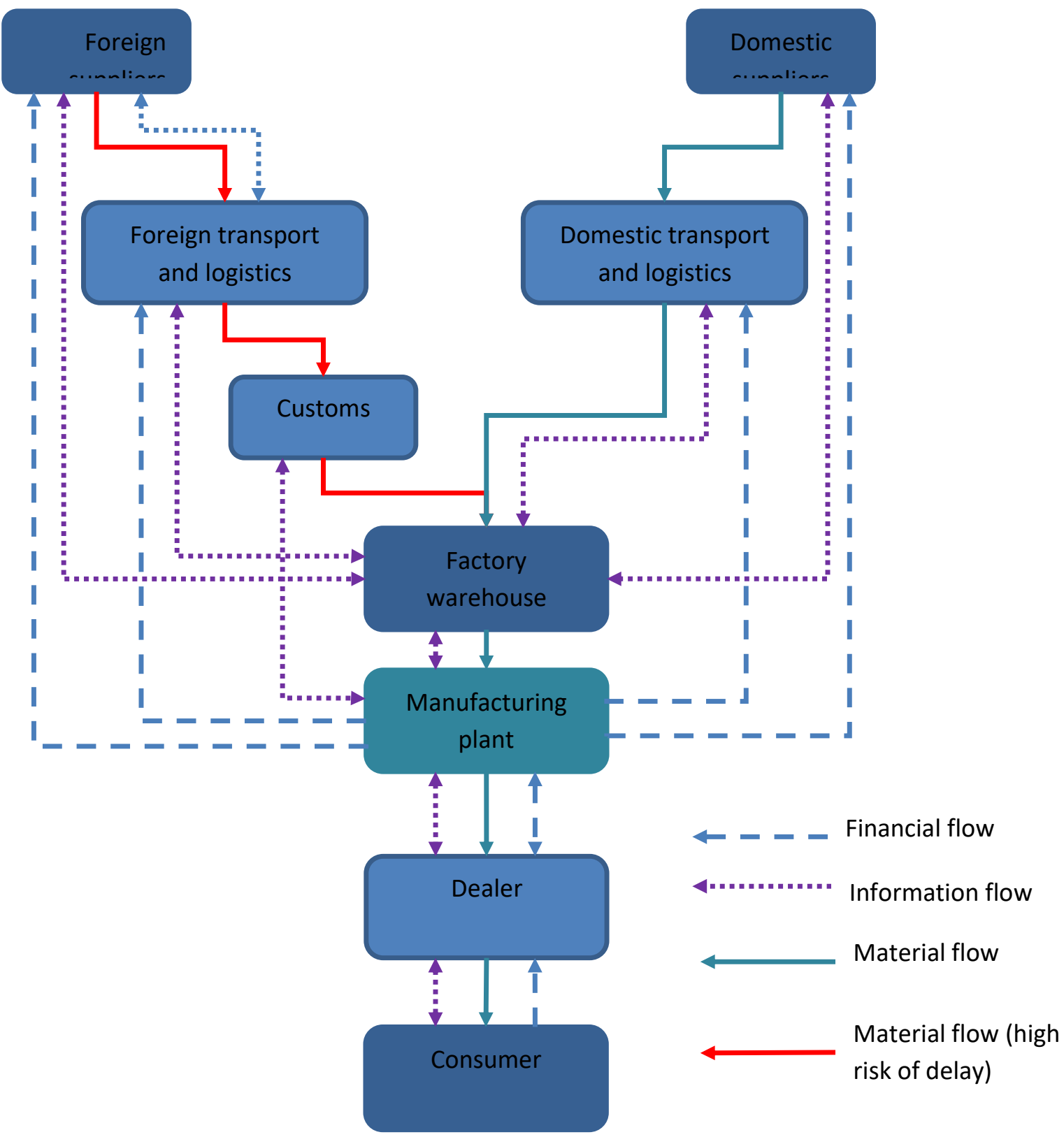

The criterion for evaluating efficiency is that the target function in the supply-production-sale system is guided by the minimum costs in each of the links separately:

$$
E_{\text {sup }}=C_{\text {sup }} \rightarrow \min , E_{\text {prod }}=C_{\text {prod }} \rightarrow \min , E_{\text {dist }}=C_{\text {dist }} \rightarrow \min
$$


where $E_{\text {sup }}, E_{\text {prod }}, E_{\text {dist }}$ are the efficiency criteria for the supply, production and sales processes, respectively, and $C_{\text {sup }}, C_{\text {prod }}, C_{\text {dist }}$ are the supply, production and sales costs, respectively.

The logistics approach is focused on refusing to consider costs in isolation; therefore, the criterion for the effectiveness of integrated logistics is the criterion for the minimum amount of these costs, the function, in this case, has the form:

$$
E_{l}=\sum\left(C_{\text {sup }}+C_{\text {prod }}+C_{\text {dist }}\right) \rightarrow \min
$$

\section{Experiment}

The process of approbation of the specified methodology for optimising business processes will be carried out at the test launch of the modernised production line of the metal structure workshop of a machine-building enterprise LLC "HITMASTERS-HAER". The modernisation process was launched in May 2017, was carried out in stages and was fully completed in November 2017. Therefore, since 2018, this production line has been operating according to the above methodology. The modernisation of production facilities was associated with the renewal of the machine tool and conveyor equipment, as well as the repair of production facilities. Since the modernisation was carried out in stages, the production process did not stop during 2019, but there was a slight decrease in its volumes compared to previous years. The economic indicators of the workshop for the three years preceding the modernisation are shown in Table 1.

Table 1. The economic indicators of the workshop before the start of the experiment (2015-2017)

\begin{tabular}{|l|c|c|c|}
\hline \multicolumn{1}{|c|}{ Economic indicator } & $\mathbf{2 0 1 5}$ & $\mathbf{2 0 1 6}$ & $\mathbf{2 0 1 7}$ \\
\hline Procurement costs - total, USD & 707046 & 736476 & 795485 \\
\hline Including raw materials, materials, components, USD & 367854 & 387562 & 428210 \\
\hline Procurement management costs - total, USD & 87669 & 95787 & 109469 \\
\hline Including, \%: & $100,00 \%$ & $100,00 \%$ & $100,00 \%$ \\
\hline $\begin{array}{l}\text { salaries of personnel involved in procurement } \\
\text { management }\end{array}$ & $48,7 \%$ & $46,7 \%$ & $47,8 \%$ \\
\hline travel expenses & $29,7 \%$ & $30,7 \%$ & $31,3 \%$ \\
\hline opportunity cost & $21,6 \%$ & $22,6 \%$ & $20,9 \%$ \\
\hline Logistics costs - total, USD; including: & 251523 & 253127 & 257806 \\
\hline container & 36463 & 37087 & 39061 \\
\hline fare & 109758 & 110479 & 112838 \\
\hline $\begin{array}{l}\text { costs of fixed and working capital for warehouse } \\
\text { purposes }\end{array}$ & 66723 & 66982 & 67328 \\
\hline storage & 38579 & 38579 & 38579 \\
\hline $\begin{array}{l}\text { Share of costs for purchasing MR in the structure of } \\
\text { total costs for procurement activities, \% }\end{array}$ & $52,0 \%$ & $52,6 \%$ & $53,8 \%$ \\
\hline $\begin{array}{l}\text { Share of procurement management costs in the total } \\
\text { cost structure, \% }\end{array}$ & $12,4 \%$ & $13,0 \%$ & $13,8 \%$ \\
\hline $\begin{array}{l}\text { Share of logistics costs in the structure of total } \\
\text { procurement costs, \% }\end{array}$ & $35,6 \%$ & $34,4 \%$ & $32,4 \%$ \\
\hline
\end{tabular}

At the same time, the specification and nomenclature of manufactured products have not changed over the past five years. Still, the volumes of certain types of products have varied depending on the market conditions. Data on production volumes for three years before the start of modernisation of the shop, as well as indicators of product profitability and inventory turnover, are presented in Table 2. 
Table 2. Data on the volume of production and evaluation of profitability and inventory turnover, for the period

\begin{tabular}{|c|c|c|c|}
\hline \multicolumn{4}{|l|}{ 2015-2017 } \\
\hline Volume of production & 2015 & 2016 & 2017 \\
\hline Finished welded trusses, USD & 614274 & 627914 & 735843 \\
\hline Gratings, USD & 335058 & 349985 & 367921 \\
\hline Power beams, USD & 279215 & 339691 & 367921 \\
\hline Corrugated flooring, USD & 223372 & 288223 & 227246 \\
\hline Welded beams (I-beams), USD & 148915 & 205873 & 194782 \\
\hline Reinforcement of various sections, USD & 260601 & 247048 & 270530 \\
\hline Total & 1861435 & 2058735 & 2164243 \\
\hline Evaluation of profitability and inventory turnover & 2015 & 2016 & 2017 \\
\hline Product profitability & 15,1 & 14,9 & 15 \\
\hline Asset turnover & 1,48 & 1,45 & 1,48 \\
\hline Inventory turnover & 2,28 & 2,68 & 2,83 \\
\hline
\end{tabular}

The process of implementing a new business process for the release of an existing product range, but using pulling logistics technology, was started in 2018, the critical goals for optimising the processes were recognised:

- reduction of inventories in intrashop warehouses;

- reduction in downtime due to waiting for necessary components from previous stages of production;

- reducing the time for moving materials and workpieces between separate locations of production;

- a decrease in the level of the barque due to a violation of the storage regime of materials

As a consequence, the implementation of this approach assumed the achievement of goals for:

- increasing the turnover of inventories;

- reducing the volume of rejections and improving the quality of finished products

- a decrease in the volume of work in progress;

- increasing labour productivity.

The global goal of all activities assumed the reduction of costs and losses, and, accordingly, an increase in the profitability of production, which was essential to reduce downtime and increase the continuity of the production process.

In the first quarter of 2018, after the start of work on a new technological process, there was an increase in time delays during the transportation of workpieces, a decrease in productivity and an increase in time losses due to a poor understanding of new technical processes by employees. In this regard, additional training was carried out for both employees and management personnel, which subsequently led to an increase in the production rate of workers, a decrease in the level of rejects in finished products and an increase in overall production efficiency. Data for the period 2017-2019 are presented in Table 3.

The result of the implementation of the business process optimisation program using pulling logistics technology was the growth of the leading indicators characterising both production efficiency and the efficiency of logistics activities, which was reflected in the cumulative, synergistic effect.

The increase in the productivity of workers after adaptation to new technological processes was more than $64 \%$ in two years, the average batch processing time was also reduced by 94 hours, the percentage of rejects due to idle time of blanks and storage in in-shop warehouses decreased by $37 \%$, and volumes also reduced work in progress by $58.7 \%$. 
Table 3. Data on changes in performance indicators of business processes in the period 2017-2019

\begin{tabular}{|c|c|c|c|c|c|}
\hline Indicator of business processes & 2017 & 2018 & 2019 & \multicolumn{2}{|c|}{ Percentage change } \\
\hline $\begin{array}{l}\text { Average cycle time (production time), } \\
\text { hours }\end{array}$ & 273 & 186 & 179 & $46,8 \%$ & $52,5 \%$ \\
\hline $\begin{array}{l}\text { Productivity of key workers (thousand } \\
\text { USD/person) }\end{array}$ & 979 & 2542 & 2742 & $61,5 \%$ & $64,3 \%$ \\
\hline Work in progress, thousand USD & 186576 & 121223 & 117567 & $53,9 \%$ & $58,7 \%$ \\
\hline Defective rate of finished products, $\%$ & 3,7 & 2,6 & 2,7 & $42,3 \%$ & $37,0 \%$ \\
\hline Product profitability & 15 & 15,5 & 16,2 & & \\
\hline Asset turnover & 1,48 & 1,76 & 1,82 & & \\
\hline Inventory turnover & 2,83 & 2,91 & 3,2 & & \\
\hline
\end{tabular}

This resulted in an increase in the profitability of finished products up to $16.2 \%$ and an increase in inventory turnover by 3.2 .

In table 4, the economic indicators of the steel structure workshop for the period from 2017 to 2019 are presented.

Optimisation of business processes and reduction of stocks of materials made it possible to reduce logistics costs for storage, transportation and maintenance of supplies of raw materials. Decrease the rejection of finished products allowed to reduce the volume of purchased materials. The optimisation allowed the steel structure workshop to save more than USD 184 thousand in 2 years.

\section{Conclusion}

It is important to note that despite the many positive aspects of using logistics technologies to optimise business processes, they can have their drawbacks. In the case of using pulling logistics technology, it is worth noting that its application for the entire production process can be associated with additional difficulties, first of all, it concerns the synchronisation of the process of the whole logistics chain for all stages of production.

Table 4. Data on the volume of production and evaluation of profitability and inventory turnover, for the period 2017-2019

\begin{tabular}{|l|c|c|c|}
\hline \multicolumn{1}{|c|}{ Economic indicator } & $\mathbf{2 0 1 7}$ & $\mathbf{2 0 1 8}$ & $\mathbf{2 0 1 9}$ \\
\hline Procurement costs - total, USD & 795485 & 709009 & 697937 \\
\hline Including raw materials, materials, components, USD & 428210 & 425520 & 423713 \\
\hline Procurement management costs - total, USD & 109469 & 89752 & 87453 \\
\hline Including, \%: & $100,00 \%$ & $100,00 \%$ & $100,00 \%$ \\
\hline salaries of personnel involved in procurement management & $47,8 \%$ & $47,8 \%$ & $47,8 \%$ \\
\hline travel expenses & $31,3 \%$ & $31,3 \%$ & $31,3 \%$ \\
\hline opportunity cost & $20,9 \%$ & $20,9 \%$ & $20,9 \%$ \\
\hline Logistics costs - total, USD; including: & 257806 & 193737 & 186771 \\
\hline container & 39061 & 28232 & 27563 \\
\hline fare & 112838 & 82345 & 79247 \\
\hline costs of fixed and working capital for warehouse purposes & 67328 & 56417 & 55389 \\
\hline storage & 38579 & 26743 & 24572 \\
\hline $\begin{array}{l}\text { Share of costs for purchasing MR in the structure of total costs for } \\
\text { procurement activities, \% }\end{array}$ & $53,8 \%$ & $57,1 \%$ & $56,6 \%$ \\
\hline $\begin{array}{l}\text { Share of procurement management costs in the total cost structure } \\
\%\end{array}$ & $13,8 \%$ & $13,6 \%$ & $13,8 \%$ \\
\hline $\begin{array}{l}\text { Share of logistics costs in the structure of total procurement costs, } \\
\%\end{array}$ & $32,4 \%$ & $29,4 \%$ & $29,5 \%$ \\
\hline
\end{tabular}


It should also be noted that the implementation of such a technique imposes increased requirements on the reliability of suppliers, in the case of a large territorial or geographical remoteness, it is necessary to calculate and include in the business process additional risks associated with delays, which naturally leads to additional costs.

Nevertheless, the use of logistics technologies and concepts in order to optimise the business processes of an enterprise has great potential. From an economic point of view, such optimisation can lead to significant savings, of course, if it is applied correctly. Logistics concepts have a set of clear rules that ensure their effectiveness. At the same time, they have sufficient flexibility to be adapted to the needs and tasks, in a specific place and under particular conditions.

\section{References}

1. Al-Dabag, N. (2005). Logistics System: The Concepts and the Principles. Tanmiyat Al-Rafidain, 27(80), 105-120, http://doi.org/10.33899/tanra.2005.161593

2. Arshinina, P. \& Kiseleva, A. (2020). Evaluation of the Effectiveness of the Logistics System. Conference: International Conference on Economics, Management and Technologies 2020 (ICEMT 2020), http://doi.org/10.2991/aebmr.k.200509.087

3. Azimov, P. (2018). Management of transport and logistics system efficiency: methodological principles. Vestnik of the Mari State University, 4 (2), 97-104, http://doi.org/10.30914/2411-96872018-4-2-97-104

4. Balan, O., Moskalyk, H., Peredalo, K., Hurman, O., Samarchenko, I., \& Revin, F. (2020). Using the Pattern Method for the Comprehensive Organization of Recruitment and Selection of Personnel. International Journal of Advanced Research in Engineering and Technology, 11(4), 290-300, http://doi.org/10.34218/IJARET.11.4.2020.029

5. Budiawan, R., Simanjuntak, J., \& Rosely, E. (2019). Inventory Management Application of Drug using FIFO Method. Test Engineering and Management, 83, 7785-7791.

6. Butcher, D. \& Rowley, J. (1998). The 7 R's of information management. Managing Information, $5(2), 4$.

7. Dzwigol, H., \& Dzwigol-Barosz, M. (2020). Sustainable Development of the Company on the Basis of Expert Assessment of the Investment Strategy. Academy of Strategic Management Journal, 19(5), 1-7.

8. Kuzior, A., Kwilinski, A., \& Tkachenko, V. (2019). Sustainable Development of Organizations Based on the Combinatorial Model of Artificial Intelligence. Entrepreneurship and Sustainability, 7(2), 1353-1376, http://doi.org/10.9770/jesi.2019.7.2(39)

9. Maleyeff, J. (2020). The Business Process. In book: Service Science, http://doi.org/10.4324/9780429320750-2

10.Manobar, M. \& Appaiah, S. (2017). Stabilisation of FIFO system and Inventory Management. International Research Journal of Engineering and Technology, 4(6), 5631-5638

11.Manzini, R., Bortolini, M., Gamberi, M., \& Montecchi, M. (2011). A Supporting Decision Tool for the Integrated Planning of a Logistic Network. http://doi.org/10.5772/18715

12.Mhanna, M. A., Ali Nabouh, A., \& Hejase, H. J. (2020). Business Process Management - BPM, http://doi.org/10.13140/RG.2.2.16140.26240

13.Oliinyk, V., \& Kozmenko S. (2019). Forecasting and management of gross domestic product. Forecasting and management of gross domestic product. Journal of International Studies, 12(4), 214-228, http://doi.org/10.14254/2071-8330.2019/12-4/14

14.Oliinyk, V., Wiebe, I., Syniavska O., \& Yatsenko, V. (2018). Optimisation model of Bass. Journal of Applied Economic Sciences, 8(62), 2168-2183.

15.Prokopenko, O., Kazanska, O., Deineha, I., Butenko, N., Omelyanenko, V., \& Bovkun, O. (2020a). Communication business processes of industrial enterprises in the conditions of globalisation. International Journal of Management, 11(5), 884-895, http://doi.org/10.34218/IJM.11.5.2020.081 
16.Prokopenko, O., Shmorgun, L., Kushniruk, V., Prokopenko, M., Slatvinska, M., \& Huliaieva, L. (2020b). Business process efficiency in a digital economy. International Journal of Management, 11(3), 122-132, http://doi.org/10.34218/IJM.11.3.2020.014

17.Quezada-Téllez, L. \& Pérez, L. (2018). A fractional logistic approach for economic growth. International Journal of Modern Physics, http://doi.org/10.1142/S0129183118501231

18.Repich, T. \& Diachkova, T. (2018). Efficiency of the logistic system of the enterprise. Efektyvna ekonomika, http://doi.org/10.32702/2307-2105-2018.12.82

19.Safran, M., Babić, D., \& Tomasic, D. (2008). Defining the Optimisation Criteria for the Functioning of Logistics and Distribution Centres. Promet - Traffic - Traffico, 20(1), 59-65, http://doi.org/10.7307/ptt.v21i1.987

20.Sezer, S. \& Abasız, T. (2017). The Impact of Logistics Industry on Economic Growth: An Application in OECD Countries. Eurasian Journal of Social Sciences, 5(1), 11-23, http://doi.org/10.15604/ejss.2017.05.01.002

21.Sherstennykov, Y. (2019). The Methodology for Modeling Logistics Systems: Implementation Principles and Examples. The Problems of Economy, 4(42), 306-314, http://doi.org/10.32983/2222-0712-2019-4-306-314

22.Shpak, N., Kyrylych, T., \& Greblikaite, J. (2016). Diversification Models of Sales Activity for Steady Development of an Enterprise. Sustainability, 8(4), DOI: 10.3390/su8040393.

23.Spofford, B., Altham, J., \& Stabler, J. (2011). Future logistics approaches, http://doi.org/10.1109/AUTEST.2011.6058782

24.Wu, P.-J. \& Chaipiyaphan, P. (2019). Diagnosis of delivery vulnerability in a logistics system for logistics risk management. The International Journal of Logistics Management, http://doi.org/10.1108/IJLM-022019-0069 